\title{
The Correlation between Organizational Culture, Transformational Leadership and Work Motivation to Teachers' Performance
}

\author{
Ramlanto, Soewarto Hadhienata, Widodo Sunaryo \\ Post Graduate Program, Universitas Pakuan Bogor, Indonesia
}

\begin{abstract}
Teachers performance is the performance of teachers in implementing duties assigned to them and is a reflections of their competence. The success of an educational organization is largely determined by the performance of its teachers, therefore their performance need to be improved. There are factors that related with teachers performances, i.e organizational culture, transformational leadership of its principal, and work motivation, which was used as independent variable in this study. This research was aimed to study the strength and direction of correlation between independent variable and dependent variable (teachers performance), either individually or jointly. This research was conducted on 202 sample of teachers selected using multistage random sampling from 11 State Junior High School in Bogor, West Java. Combination method of quantitative and qualitative with sequential explanatory design was used in this study. The data was analysed using regression and partial correlation, simple correlation, and double correlation. The results showed that there is a significant and positive correlation between independent variable, consist of organizational culture, transformational leadership, and work motivation jointly, with teachers performance as dependent variable. The correlation coefficient is $r_{y .123}=0.562$ and coefficient of determination is $r_{y .12}^{2}=0.316$. This means that all variables simultaneously have positive and significant correlation with teachers performance. These variable contribution are $31.6 \%$, while the other factors contribution are $68,4 \%$.
\end{abstract}

Keywords: Teachers performance, organizational culture, transformational leadership, and work motivation .

\section{INTRODUCTION}

The job of being a teacher cannot be done by people who do not have specific skills and qualifications as a teacher. The teacher is a profession which along with the time development has a heavier role and task requiring more innovative performance. More innovative teacher performance is crucial for the successful implementation of education in order to improve the quality of education.

Teacher performance is the assessment on the performance in carrying out the tasks assigned reflected in the output produced both in quality and quantity. The performance of teachers is part of the school organization's performance, so the performance of teachers is very important and needs to be improved in order to increase organizational performance. The teacher's performance is also a reflection of its competence. Based on Law No. 14 Year 2005 on Teachers and Lecturers, in Article 10, paragraph (1) it is stated that the competence of teachers referred to in Article 8 includes pedagogical competence, personal competence, social competence, and professional competence acquired through professional education.

Evidence from the field suggests that most teachers do not perform optimally based on the results of a preliminary survey on teacher performance of Junior High School in Bogor, Indonesia. The survey was conducted by distributing questionnaires to 30 respondents from the four schools. The results of teacher performance appraisal is done by five (5) performance indicators as follows: (a) the percentage of teachers who have been able to create a syllabus and Learning Implementation Plan (RPP) in accordance with the standard process, has reached 59\%; (B) the percentage of the number of teachers who have been able to carry out learning methods vary according to the characteristics of the new subjects reached $60 \%$; (C) the percentage of teachers who have been able to draw up an evaluation tool of learning outcomes in accordance with the new indicator reached $60 \%$; (D) the percentage of teachers who are able to analyze the results of the evaluation of learning and 


\section{Ramlanto et al.}

implementing the follow-up program has only reached $61 \%$; (E) the percentage of teachers who are able to communicate the learning smoothly has just reached $61 \%$. If averaged the performance of teachers of Junior High School in the city of Bogor reached 60. $2 \%$ which can be considered as still low.

This study aims to examine the performance of Junior High School teacher in the city of Bogor in an effort to carry out their duties and responsibilities as well as studying the variables related and the effect. The variables suspected of having links with teacher performance, namely: job satisfaction, organizational culture, teacher innovation, transformational leadership, work environment, emotional intelligence, interpersonal communication, job commitment of teachers, academic qualifications, motivation, discipline, time and community participation. With all the limitations, this research variables which will be further examined the relationship between organizational culture, transformational leadership and motivation to work with teacher performance.

Based on the background and restriction issues to be examined in this study, it can be formulated main points as follows:

1. Is there a relationship between organizational culture with the teacher's performance?

2. Is there a relationship between transformational leadership with teacher performance?

3. Is there a relationship between work motivation with teachers performance?

4. Is there a relationship between organizational culture, transformational leadership and motivation to work together with the teacher's performance?

\section{LiterATURE REVIEW}

Performance is defined by Colquitt, J.A, Lepine and Wesson (2009) as the value of the set behavior of someone who contributes, either positively or negatively, to the achievement of organizational goals. This definition includes behavior without control, but still within the limits of the relevant behavior, not on job performance. In general, behaviors that can be divided into three categories: behavior in performing the task, the behavior as citizens and unproductive behavior that contributed negatively to the organization.

Newstrom (2008) states that "performance is satisfactory feedback enhancing employee's self-image and feeling of competence. Performance feedback leads to both improved performance and improved attitude. Performance feedback leads to improvements in performance and changes in attitudes.

Rue and Byars (2007) defines performance refers to how well a teacher in meeting the requirements of the job determined by three main factors, namely: effort, ability and direction. These three factors mentioned above certainly has a direct causal effect; because they are interrelated. If one factor is not owned by a teacher, the performance will be low.

James L. Gibson et. al (2003) defines that a person's performance will be crucial for the performance of the organization. The performance of the individual is the basis for the performance of the organization, the higher the performance of the individual, the higher the achievement of organizational performance.

Based on existing theoretical studies, it can be synthesized, that the performance is the performance of teachers in carrying out the tasks assigned reflected in the output produced good quality of quantity. As for the indicators that show the performance of teachers is (a). lesson plans; (B) the implementation of learning; (C) evaluation of learning; (D) following up the results of the evaluation, and (e) of interpersonal communication.

According to Gibson et al. (2009) in his book "Organizational: Behaviour, Stucture, Processes" suggest that organizational culture is what is perceived by the workers and how this perception can create the beliefs, values and expectations. This means the higher the confidence and the expectation, the greater the cultural awareness.

Organizational culture is informal values and norms of control for individuals and groups within the organization to interact with each other and with people outside the organization. Organizational culture is formed from the interaction of people and the values of the existing regulations within the 
organization. As stated by Gareth R. Jones (2007); "organizational culture is the set of shared values and norms that control organizational members interaction with each other and with suppliers, customers, and other people outside the organization

Mullins in his book mentions that organizational culture is a reflection of the underlying assumptions about how work is done, what is allowed and what is forbidden, and attitude and behavior what it evokes and reduce morale. Three things that affect the culture of the organization, namely; 1). working, 2). behavior, and 3). conduct.

Kinicki and Brian K. Williams (2008) defines organizational culture is a system of beliefs and values that thrive in an organization and guide the behavior of its members. Organizational culture is a social glue and binder all members of the organization. This will lead members of the organization to have a personality, pleasure, love, warmth, anxiety, rivalry. Each agency has a different organizational culture; ranging from the treatment of employees, team work, the regulations in effect, conflict, and awards.

Jennifer M.George and Gareth R. Jones (2008), defines the culture of the organization is on the form of the role of values, beliefs and norms that affect the way employees to think, feel and behave towards each other and towards those outside organization, with factors the role of values, beliefs and norms that affect the way employees think, feel and behave towards each other.

Based on the description and understanding of the organizational culture theory above, it can be synthesized that organizational culture is a shared perspective on the values, norms, and beliefs of individuals in the organization that is formed from the interaction between members to achieve common goals. The indicators that show the culture of the organization, namely: 1). application of norms, 2). confidence in the consensus value 3). confidence in the organization, 4). integration with fellow members of the organization, 5). clear ownership of the roadmap 6). seriousness of the joint achievement and 7). working principle of the agreed personnel within the organization.

Gary Yukl (2006), transformational leadership is leadership that affects followers to feel trust, admired, have the loyalty and respect to the leader, as well as motivate them to do more than is expected.

Transformational leadership by Rue and Byars (2007) is a leadership that takes into account the group's mission in employee recruitment.

Bass and Riggio (2006) explains that transformational leadership is leadership that can mobilize followers to exceed the expected performance, and results in higher levels of satisfaction and commitment followers to groups and organizations.

Robbins (2006) mentions that the characteristics of transformational leaders, namely: (A) having charisma, which provide a vision and a sense of the mission, instilling pride, won the respect and trust; (B) Inspiration, which communicates high expectations, uses symbols to focus on the business, and describes the critical points in a simple way ; (C) intellectual stimulation, which is to encourage intelligence, rationality, and solve problems carefully; (D) Consideration of the individual, namely providing personal attention, serving personally, coaching and mentoring.

Colquitt et al., (2009) defines leadership as the use of power and influence to direct the activities of followers towards achieving objectives.

Based on a number of the above theory, it can be synthesized that transformational leadership is behavior affecting followers able to change something better to the values espoused by members of the organization so that good relations between members of the organization can be built reflected in a climate of mutual trust in order to realize the vision, mission and goals of the organization. The factors that demonstrate transformational leadership are: a). the influence of the charismatic ideal, b). individual consideration, c) intellectual stimulation, d) the motivation that inspires.

Motivation comes from the word motive which can be interpreted as affecting the driving force to begin conducting a series of activities. According Sardiman (2007) motivation might be seen as a change of energy in a person characterized by the appearance of feeling, and preceded with the response to their destination. 
According Luthans, (2011) motivation is a process that begins with physiological or psychological deficiencies that drive behavior or encouragement intended for incentive purposes. The factors that showed motivation to work are: a) interact; b) each depending on the needs; c) encouragement; d) incentives.

According to Gibson et.al, (2012) "motivation is forces acting on an employee that initiate and direct behavior. This concept explain differences in the intensity of behavior regarding more intense behavior as the result of higher levels of motivation and also to indicate the direction of behavior. This concept suggests that behavior is more frequently manifested in increasing motivation. The factors that showed motivation to work are: a) drive and b) directing behavior.

Based on the theories above, it can be synthesized that motivation is a force to encourage, stimulate and steer both from within and from outside to act and behave in order to achieve the stated goals of both individuals and organizations. The factors that showed work motivation based on the internal dimensions are: a) responsibilities; b) self-development; c) independence; d) attempt to meet the needs of the work, and the factors that showed motivation to work based on the external dimensions are: e) interpersonal relationships; f) work with the hope to get incentives; g) work with the hope of getting the attention of superiors.

Based on the study of theory and framework as described above, the following hypothesis is formulated:

1. There is a positive relationship between organizational culture with teacher performance.

2. There is a positive relationship between transformational leadership with teacher performance,

3. There is a positive relationship between work motivation and teacher performance.

4. There is a positive relationship between organizational culture, transformational leadership and motivation to work simultaneously with the performance of teachers.

\section{Methodology}

This study applies Sequential Explanatory Design Mixed Method where quantiative study is ahead of qualitative study to examine the relationship between variables tested in the study using three independent variables through data obtained from questionnaires. The independent variable is Organizational Culture $\left(\mathrm{X}_{1}\right)$, Transformational Leadership $\left(\mathrm{X}_{2}\right)$, and Working Motivation $\left(\mathrm{X}_{3}\right)$, while the dependent variable is the Teacher's Performance Y).

The relationship among variables in the study described in Fig.1 below:

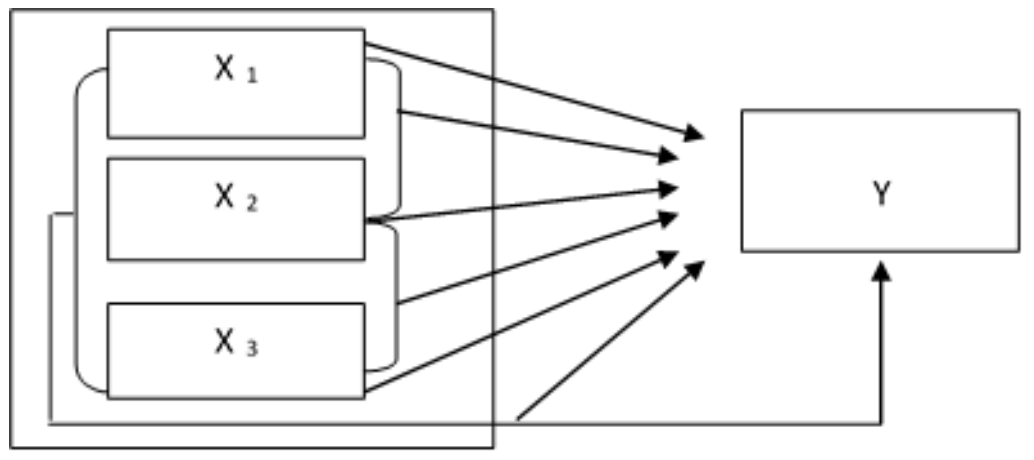

Figure1. Theoretical Framework

where,

$\mathrm{Y}=$ Teacher's Performance

$\mathrm{X}_{1}=$ Organizational Culture

$\mathrm{X}_{2}=$ Transformational Leadership

$\mathrm{X}_{3}=$ Working Motivation

The sampling technique is to count the number of samples by using the Slovin's formula generating samples obtained as many as 202 out of 408 teachers. Hypothesis testing is conducted by using regression analysis to determine the influence of one or more independent variables on the dependent 
variable. The normality assumption with Liliefors test are prerequisites to proceed to further test. Hypothesis testing is performed at a significance level of 0.05 .

Qualitative study for the purpose of confirmation was performed through observation and interview to key informant as well as conducting focus group discussion with school principal and teachers.

\section{RESUlT AND DISCUSSION}

The teachers of listed organisations were asked to participate in the survey by responding their opinions for four different measures in organizational culture, leadership, work satisfaction and performance. Data is normal as the value of each variable $=0.053,0.047,0.045$ below the critical value Liliefors test for $\mathrm{N}=2012$ which is 0.062 .

\subsection{Organizational Culture and Teachers' Performance}

Since the data is normally distributed, we can proceed to test the alternate hypothesis if organizational culture is positively related to teachers' performance within junior high school organisations in Bogor, Indonesia. The strength of association of organizational culture $\left(\mathrm{X}_{1}\right)$ to teacher's performance $(\mathrm{Y})$ is observable from coefficient correlation $\left(\mathrm{r}_{\mathrm{x} 1}\right)=0.551 . \mathrm{T}_{\text {test }}=9.34$ is above critical value where $\mathrm{T}_{\text {-tabel }}$ for $(\alpha=0.05)$ is 1.97 indicating that the relationship is significant confirming the first hypothesis that organizational culture is positively related to teachers' performance. Coefficient of determination $\left(r_{x}^{2} 1\right)=0.304$ indicates that contribution of organizational culture to teachers' performance is $30.4 \%$.

Similarly, result of qualitative research interviews, observation and documentation confirms the tendency of the relationship between organizational culture to teachers' performance. This finding strengthens the quantitative research hypothesis results testing that there is a positive significant relationship between organizational culture to teachers' performance.

This finding is in line with Heriyanti (2007) who found out that organizational culture as the form of the role of values, beliefs and norms that affect the way employees to think, feel and behave towards each other and towards those outside organization has significant impact on performance.

\subsection{Transformational Leadership and Teachers' Performance}

Since the data is normally distributed, we can proceed to test the alternate hypothesis if transformational leadership is positively related to teachers' performance within junior high school organisations in Bogor, Indonesia. The strength of association of transformational leadership $\left(\mathrm{X}_{2}\right)$ to teacher's performance $(Y)$ is observable from coefficient correlation $\left(r_{x 2}\right)=0.432 . T_{\text {test }}=6.78$ is above critical value where $T_{\text {tabel }}$ for $(\alpha=0.05)$ is 1.97 indicating that the relationship is significant confirming the second hypothesis that transformational leadership is positively related to teachers' performance.Coefficient of determination $\left(\mathrm{r}_{\mathrm{x} 2}^{2}\right)=0.187$ indicates that contribution of transformational leadership to teachers' performance is $18.7 \%$.

Similarly, result of qualitative research interviews, observation and documentation confirms the tendency of the relationship between transformational leadership to teachers' performance. This finding strengthens the quantitative research hypothesis results testing that there is a positive significant relationship between transformational leadership to teachers' performance.

This finding is in line with Baihaqi \& Suharnomo (2010) who found out that transformational leadership as leadership that affects followers to feel trust, admired, have the loyalty and respect to the leader, as well as motivate them to do more than is expected has significant impact on performance.

\subsection{Working Motivation and Teachers' Performance}

Similar to previous model, since the data is normally distributed, we can proceed to test the alternate hypothesis if working motivation is positively related to teachers' performance within junior high school organisations in Bogor, Indonesia. The strength of association of working motivation $\left(\mathrm{X}_{3}\right)$ to teacher's performance $(Y)$ is observable from coefficient correlation $\left(r_{x 3}\right)=0.406$. $T_{\text {test }}=6.29$ is above critical value where $\mathrm{T}_{\text {-tabel }}$ for $(\alpha=0.05)$ is 1.97 indicating that the relationship is significant confirming the third hypothesis that working motivation is positively related to teachers' performance. Coefficient of determination $\left(\mathrm{r}_{\mathrm{x} 3}^{2}\right)=0.165$ indicates that contribution of working motivation to teachers' performance is $16.5 \%$. 
Similarly, result of qualitative research interviews, observation and documentation confirms the tendency of the relationship between working motivation to teachers' performance. This finding strengthens the quantitative research hypothesis results testing that there is a positive significant relationship between working motivation to teachers' performance.

This finding is in line with Riyadi (2011) who found out that motivation as a force to encourage, stimulate and steer both from within and from outside to act and behave in order to achieve the stated goals of both individuals and organizations has significant impact on performance.

\subsection{Organizational Culture, Transformational Leadership and Working Motivation to Teachers' Performance}

The result showed that there is a positive relationship between organizational culture, transformational leadership and motivation to work together with the performance of teachers. This is indicated by the correlation coefficient $=0.562$. Contributions of organizational culture, transformational leadership and motivation to work together on teacher performance are $31.6 \%$, which is expressed by the coefficient of determination $=0.316$. The pattern of the relationship between organizational culture, transformational leadership and motivation to work together with the teacher's performance demonstrated by the multiple linear regression equation $y=62.53+0.34 X_{1}+0.09 X_{2}+0.05 X_{3}$.

The results of this study indicate that organizational culture, transformational leadership of principals, and motivated teacher strongly correlate together with the performance of teachers. This way, school leader seeks to influence each teacher to involve in activities to provide the best service in an effort to increase productivity and performance of organization. Organizational culture is daily embodiment of traditional values that underlie the organization of the school and observable from how teachers behave, expectations of teachers to school and vice versa. Organizational culture that is nurtured well will affect the behavior of teachers which in turn will affect the job performance of teachers. Their organizational culture applies the norms and values, the determination of the vision and mission of the school as a reference of principals, teachers and other school communities in their duties. Teachers and other school communities are to comply with prescribed rules, provide exemplary, performing work with full responsibility, and their confidence in the organization respond quickly to technological change. Transformational leadership of principals apply the standard of school quality and transparency of information, appear charismatic, as a role model, as a mentor for teachers, able to motivate, stimulate intellectual and aware of the needs of teachers who are creative, innovative so that teachers are motivated to continue to develop themselves and capable to become independent and responsible to the job, then it will jointly associated with increased teacher performance. The performance of a teacher is the resulting behavior of a teacher in duties as a teacher and educator in the school.

\section{CONClusion}

The findings prove that there is a positive and significant relationship between the organizational culture on teachers' performance, transformational leadership on teachers' performance and working motivation on teachers' performance among teachers working in junior highs located in Bogor, Indonesia. With particular reference to initial design of the interaction among variables, the results showed that the contribution of organizational culture variable on teachers' performance is $30.4 \%$, transformational leadership is $18.7 \%$, and working motivation is $16.5 \%$ indicating the highest individual contribution to the performance of teachers is organizational culture. When combined together, contribution of the three variables of organizational culture, transformational leadership and working motivation achieve $31 \%$ indicating the contribution of other variables not included in the model to predict junior high school teachers' performance are only $69 \%$.

Based on interviews in qualitative study it is revealed other factors than organizational culture, transformational leadership, and motivation of teachers associated with teachers' performance Those factors are the school facilities and infrastructure, job satisfaction of teachers, the working environment of teachers, teachers' working discipline, intellectual and emotional intelligence of teachers, teacher work commitment, achievement motivation and teachers' work culture. 


\section{REFERENCES}

Baihaqi, M. F., \& SUHARNOMO, S. (2010). Pengaruh Gaya Kepemimpinan terhadap Kepuasan Kerja dan Kinerja dengan Komitmen Organisasi sebagai Variabel Intervening (Studi pada PT. Yudhistira Ghalia Indonesia area Yogyakarta) (Doctoral dissertation, Universitas Diponegoro).

Bernard M. Bass \& Ronald E. Riggio, Transformational Leadership,(New Jersey: Lawrence Erlbaum associates, Publishers, 2006), pp. 3-6.

Colquitt, J., Lepine, J. A., \& Wesson, M. J., Organizational behavior: Improving performance and commitment in the workplace. McGraw-Hill/Irwin, 2009, ch.2 pp. 66-70.

Gary Yukl, Leadership in Organizations ,(New York: Pearson Education International, 2006), pp.251 $\& 254$

Gibson James M. 2006.,Organizations: Behavior, Structur, Processes, International Edition, New York: Mc Graw-Hill Companies .

Heriyanti, D. (2007). Analisis Pengaruh Budaya Organisasi, Kepuasan Kerja, dan Gaya Kepemimpinan terhadap Kinerja Karyawan dengan Komitmen Organisasional Sebagai Variabel Interverning (Studi PT. PLN (Persero) APJ Semarang)(Doctoral dissertation, program Pascasarjana Universitas Diponegoro).

Jason A. Colquit., Jeffery A, Lepine and Michel J Wessor, Organizational Improving Performance and Commitmen in the Workplace, (New York MicGraw Hill/Irwin, 2009), pp. 546-551

Jennifer M. Georde and Gareth R .Jone,2008. Understanding and Management: Behaviour, Person Education, Inc Upper Saddle River, New Jersey, p. 567.

Kinicki, Angelo and Brian K. Wiliams. 2008, Management A practical Introduction, New York: Mc Grow Hill, p.248.

Luthans, Fred. 2011. Organizational behaviour: An Evidence-Based Approach, Mc Graw-Hill Irwin Companies. P.71

Newstrom John W, 2008. Organizational Behaviour: Human Behaviour at Work New York: McGraw-Hill Inc., p: 140

Riyadi, S. (2011). Pengaruh Kompensasi Finansial, Gaya Kepemimpinan, dan Motivasi Kerja Terhadap Kinerja Karyawan pada Perusahaan Manufaktur di Jawa Timur. Jurnal Manajemen dan Kewirausahaan (Journal of Management and Entrepreneurship), 13(1), 40-45.

Robbins, S. P. 2006. Perilaku Organisasi (diterjemahkan oleh Bunyamin Molan). Jakarta: Indeks.p. 472

Sardiman A.M., 2007. Interaksi dan Motivasi Belajar Mengajar, Jakarta, Rajawali, p. 73 